10. Herrera Anchustegui, I. The Social Market Economy and the European Union [Text] / I. Herrera Anchustegui // SSRN Electronic Journal. - 2016. doi:10.2139/ssrn.2793698

11. Bisi, M. Some kinetic models for a market economy [Text]/ M. Bisi // Bollettino dell'Unione Matematica Italiana. - 2016. Vol. 10, No. 1. - P. 143-158. doi:10.1007/s40574-016-0099-4

12. Konov, J. I. Market Economy under Rapid Globalization and Rising Productivity [Text] / J. I. Konov // Scholedge International Journal of Management \& Development. - 2015. Vol. 2, No. 9. - P. 9. doi:10.19085/sijmd.020902

13. Mochernyi, S. V. Ekonomichnyi entsyklopedychnyi slovnyk [Text] / S. V. Mochernyi, Ya. S. Larina, O. A. Ustenko, S. I. Yurii ed. by S. V. Mochernyi. - Lviv: Svit, 2006. - Vol. 2. - 568 p.

14. Martsyn, V. S. Stanovlennia rynkovoi ekonomiky v Ukraini (problemy i perspektyvy) [Text] / V. S. Martsyn. - Lviv: Kooposvita, 1999. - 284 p.

15. Dziubyk, S. D. Osnovy ekonomichnoi teorii [Text]: Handbook S. D. Dziubyk. - Kyiv: Znannia, 2014. - 423 p.

16. Yanova, V. V. Ekonomika. Kurs lektsii [Text]: Handbook V. V. Yanova. - Moscow: Ekzamen, 2005. - 384 p.

17. Fedorenko, V. H. Politychna ekonomiia [Text]: Handbook / V. H. Fedorenko. - Kyiv: Alerta, 2015. - 487 p.

18. Stechenko, D. M. Derzhavne rehuliuvannia ekonomiky [Text] Handbook / D. M. Stechenko. - Kyiv: Znannia, 2007. - 310 p.

\section{ИССЛЕДОВАНИЕ ЛРЕИМУЩЕСТВ И НЕДОСТАТКОВ РЫНОЧНОЙ ЗКОНОМИКИ}

Проведен анализ понятия рыночной экономики. Рассмотрены положительные и отрицательные стороны рыночной экономики, а также правильности трактовки данного термина согласно современным тенденций. Сделан вывод о том, как правильно, по мнению авторов, нужно трактовать само понятие «рыночная экономика». Также проанализированы изменения состояния экономики стран, перешедших на рыночную экономику, а именно: Эстония, Латвия, Литва.

Ключевые слова: рыночная экономика, преимущества и недостатки рыночной экономики, валовой внутренний продукт (ВВП), экспорт стран Прибалтики.

Filipova Liubov, PhD, Associate Professor, Department of Economic Cybernetics, University of the State Fiscal Service of Ukraine, Irpen, Kyiv Region, Ukraine, e-mail: l_filippova@ukr.net, ORCID: https:// orcid.org/0000-0001-6651-9444

Tushynska Valentyna, Department of Economic Cybernetics, University of the State Fiscal Service of Ukraine, Irpen, Kyiv Region, Ukraine,e-mail:V.Tushinskaia@utc.biz.ua,ORCID: https://orcid.org/ 0000-0003-3628-6066
Guliyeva A. Rzayeva U.

\title{
ANALYSIS OF THE DE-DOLLARIZATION PROBLEM IN DEVELOPING COUNTRIES ON THE EXAMPLE OF AZERBAIJAN IN THE CONDITIONS OF GEOPOLITICAL ASYMMETRY
}

Вивчена геополітична асиметрія інтересів між розвиненими та країнами, що розвиваються. В умовах глобальної кризи питання дедолларизації стає актуальним $i$ з політичної, $i$ з економічної точки зору. Розглянуто проблему невеликої держави, що виникла на тлі нафтової пастки i поступової відмови від використання долара США в якості валюти міжнародних розрахунків.

Ключові слова: геостратегічна нестабільність, антидоларова кампанія, розвиток підприємництва, фондовий ринок, золото як грошова одиниия.

\section{Introduction}

The concept of asymmetry, i. e. disproportion, discrepancy was included into an arsenal of mathematics and physics long ago. Asymmetry belongs to usual, widespread natural phenomena (geological, biological and other). [1] reveals in detail how asymmetry turned out to be an important aspect in most, even in each known geopolitical relations. By [2] the asymmetric strategy always presents in relationships. [3] suggests that all modern asymmetric conflicts can be understood when they are considered through the prism of the strategy and concludes that asymmetry is a strategy and strategy is an asymmetry.

At the beginning of the XXI century significant changes were observed in all characteristics due to radical shifts in the global economy. Today the USA as the largest importer of oil and the only superstate monopolized the right to convert geopolitics of spaces into geopolitics of streams, geostrategy in geoeconomy and vice versa. Both sellers and buyers prefer to conduct calculations in dollars in order to avoid unnecessary transaction costs. From this perspective, the greatest danger is political: any trade in the national currency is a blow to the dollar, and the US usually does not leave strikes without an answer.

In foreign trade, economic dependence is manifested not only in the overall asymmetry of exports and imports, but also primarily in the commodity structure of these composite. Based on the survey of 20 countries, it is clear that abnormal revenues from the mineral resources' export, as well as an excess of this resource within the country generate deformation of economy in all cases, regardless of the political system and the applied economic policy [4]. This problem is doubly urgent for Azerbaijan, as raw 
materials and semi-finished products are mainly dominated in the exports of developing countries.

At the heart of all geopolitical conflicts, along with objective reasons, there is also information, economic and political asymmetries. The article draws parallels between the problem of de-dollarization, «resource curse» and development directions of the non-oil sector in Azerbaijan.

\section{The object of research and its technological audit}

For objective reasons, the international unit of account for today is the US dollar, and other countries are forced to widely use foreign currency for their mutual settlements. The use of foreign currency has a number of negative consequences, for example, dependence on fluctuations in the exchange rates of third-country currencies (their economies) and dependence on the use of their payment systems. In this regard, it is necessary to conduct a theoretical analysis of payment systems' place in the financial infrastructure, the features of the process in payment systems' integration based on the study of European countries' experience that have advanced in this issue. Despite certain differences, the issues of further reforming all payment systems' architecture remain common to them, both in the context of the continuous development in information technologies and in the conditions of qualitative and quantitative changes on national and global financial markets. These issues have been resolved by central banks regarding their payment systems in recent years, and an important achievement was the beginning of various payment systems' integration among themselves into single intraregional payment systems, such as TARGET2 within the European Union. From this point of view, increasing technical cooperation, encouraging the use of national currencies in mutual settlements in bilateral trade, can strengthen economic positions [5]. Speaking of Azerbaijan, our country and Iran have begun exploring the possibilities for integrating the card systems in two countries.

If we adhere to the line of economies' de-dollarization, the development of the crypto-currency exchanges appears as a worthy option, although there is necessity of studying this question's all aspects more thoroughly. IBM has developed a system of international currency settlements based on the «blockchain» technology. The system works so far only in a pair of British pound - Fiji dollar. However, soon it is planned to expand this trend to several currencies in Oceania countries, including Australian and New Zealand dollars, as well as the currency of pa'anga that is used in the Tonga Islands. It is expected that the system will serve up to $60 \%$ of the international retail market in the South Pacific region. In the future, IBM's system can become a competitor to SWIFT or can replace the current SWIFT software [6]. Crypto-currencies can replace the dollar in developing countries with weak national currencies [7].

To date, most of the population in Azerbaijan has no idea of the bitcoin, and even less have an idea of the blockchain technology. But here steps towards cryptocurrencies are already being made. The possibility of creating a «crypto-manat» (the crypto-currency equivalent of the Azerbaijani manat) is actively discussing in the government. It should be noted that Azerbaijani legislation prohibits all means of payment different from Azerbaijani manat.

\section{The aim and objectives of research}

The aim of research is investigation of the global asymmetry, which is caused by the dominance of the dollar and has the greatest impact on countries whose economies depend on energy exports. Azerbaijan is in the list of such countries.

To achieve this aim it is necessary to:

1. Define suggestions of ways for escaping the global asymmetry in the light of the diminishing returns from the oil sale.

2. Conduct a critical analysis of internal market's structure and find out why raw materials and semi-finished products are mainly dominated in the exports of developing countries.

3. Examine steps that Azerbaijan government should take towards the development of the non-oil sector (we do not take into consideration such fields of economy as agriculture, tourism, information technologies, etc.)

4. Present authors' vision of solving the de-dollarization problem from positions of small developing country.

\section{Research of existing solutions of the problem}

The concept of «oil geopolitics» has taken root in global political usage, at least since the late 1970s, especially after the US Senate Committee on Energy and Natural Resources held hearings on this topic in 1980 [8]. The subjects of oil geopolitics are the distribution of oil reserves on the Earth and the routes of oil delivery to different points of the planet; these subjects are treated by geopolitics from the point of view of the interested powers' security, in conjunction with the block and world civilization divisions and with the antagonisms which are developed in them [9]. [10] explores how in the modern world the position of the exporter and consumer of fuel is characterized by the fundamental geopolitical asymmetry. First, it is obvious that money is scarcer than fuel (the consequence of this is the danger of the monetary withdrawal from oil production into spheres with a more rapid return). The attempt of oil exporters in the 1970s to turn around this situation ended in failure. Secondly, our world is designed in such a way that geopolitics is reduced to geo-economics for exporters - investors and buyers' searches, agreements on volumes of production with other exporters, pipelines' laying (without including geostrategy at all). The producer and exporter of oil does not control the regions to which it flows, and, as a rule, even those areas through which it flows. Meanwhile, the largest oil consumers since the era of the world colonial division have consistently used force control over the oil production areas to strengthen and optimize their geoeconomic positions: for them the geopolitics of oil has always been not only geoeconomics but also geostrategy.

Analyzing the structure of the distribution of world oil reserves, [11] concludes that the asymmetry and polarization of hydrocarbon resources (along with some regional differentiation) increases in a small group of developing countries and countries with transitional economies, which are one of the prerequisites for the revival of «resource nationalism». [12] shows the specifics of the current situation on the world oil market in the formation of a new 
imbalance between supply and demand, and there are two key points: a sharp increase in dependence of countriesconsumers of energy resources on countries-producers (growth of market's asymmetry) and the achievement of peak growth of the world production (oil peak), which leads to the need investments in the development of less profitable and remote fields, to develop the production of alternative energy sources and/or to establish control over the oil producing countries up to the force capture. This explains the extreme instability of the oil market, which manifests itself in the extreme aggravation of the overall geopolitical situation and high price volatility. Rigid orientation of the USA to the unipolar world founded on exclusively power methods of the problems' solution connecting with control over resources was a consequence of it.

Historically, commodity markets have used the US currency as a settlement facility. Traditionally, oil quotations are exposed in US dollars. You can pay for the goods in any currency, but the estimate is always made in dollars.

As a result, companies and governments of states that buy oil and oil products keep large dollar reserves for payment of oil supplies, which in turn facilitates the position of the US economy, allowing the US to close a large trade deficit.

[13] determines that the rejection of the dollar in mutual settlements in relations between Cuba, Bolivia, Venezuela, Honduras, Nicaragua and Ecuador occurred in 2009. The states that are members of The Bolivarian Alliance for the Peoples' of Our America (ALBA) have accepted a new currency for mutual settlements, refusing the US dollar. The first deal with the use of Ecuadorian sucre was signed between Havana and Venezuela.

It was also announced that China and Brazil can now make payments in yuan. Moreover, Brazil aimed to a gradual departure from dollar settlements, not only with China, but also with the BRIC (Brazil, Russia, India, and China) countries. The success of such calculations was confirmed by experience with Argentina.

An active anti-dollar campaign is developing in the world. The Chinese monetary authorities proposed their plan for reforming the world financial system, which involved the creation of an international reserve currency. According to the Central Bank of China, special drawing rights (SDR) - an artificial payment facility IMF, tied to a basket of currencies could become an international reserve currency [14].

At the summit of the Shanghai Cooperation Organization in 2008, the idea of rejecting the dollar in the calculations between Russia and China sounded [15]. It was proposed to replace it with the Russian ruble or the Chinese yuan. Two countries were able to conduct trade operations among themselves in their national currencies, although it concerned only the border areas.

And yet at the moment there is no tangible threat to the dollar as the only currency of the oil contract. $60-70 \%$ of export operations in the world are carried out in dollars. About $60 \%$ of all foreign exchange reserves of countries are also in dollars, $80 \%$ of transactions in the world currency market are carried out in dollars and $70 \%$ of bank loans are provided in dollars.

The issue of de-dollarization goes far beyond the economy. These attempts sometimes lead to serious and far from positive developments in world politics. For example, as it was given by the theory existing in the western media that invasion of the USA into Iraq began after S. Hussein had demanded that within the «Oil in exchange for food» program calculations would be carried out in euro, but not in the American dollars [16].

In 2009, Muammar Gaddafi, the head of Libya and the president of the African Union, invited African countries to switch the new currency «gold dinar», independent of the US dollar and the African franc. Gaddafi called for the creation of a monetary union in which the main means of paying for oil and other resources would be gold dinar. This idea, according to economist Frederick William Engdahl, was approved by the leaders of Tunisia and Egypt Zin el-Abidine Ben Ali and Hosni Mubarak. According to [17], not human rights violations in Libya, but the attempt to de-dollarization was the main reason why Hosni Mubarak and Gaddafi were killed.

It is possible that this is not the last war for the dollar stability. In 2016, Iran announced plans to open an oil exchange where the price of oil would be quoted in euros. The news aroused serious concern in the oil circles. The geographical location of the country in proximity to such important oil and gas importers as China, India and Europe determines the strategic importance of Iran as a world oil supplier. Iran has 158.400 millions of barrels of proven hydrocarbon reserves, or $10 \%$ of the world's reserves [18]. Yet at the beginning of 2016, Iranian authorities chose the euro in the calculations for oil supplies in new contracts, the Islamic Republic required payment in European currency.

From this perspective, the greatest danger is political: any trade in the national currency is a blow to the dollar, and the US usually does not leave strikes without an answer.

Now put the policy aside, talk about the economy.

The sale of oil for the national currency is a controversial issue. Let's imagine that a foreign buyer wants to pay for oil in the national monetary standard. He comes with dollars or euro, submits the application for their exchange for national currency, at the same time he undertakes risks of change of the course. After receiving national currency, money is enlisted into the account of sellers. However, there is also other party. Oil industry workers buy the equipment abroad for dollars or euro. In case of switching to the national currency, they also have to exchange it, sell it, buy dollars again, and take risks for changing the exchange rate. In this situation, as [19] describes both sellers and buyers prefer to conduct calculations in dollars in order to avoid unnecessary transaction costs.

What other external factors prevent oil from being sold for national currency? First, the main factor is already settled system of trade generally for the American dollar. Actually, America remains the main consumer of hydrocarbon raw materials. In addition, the second external factor is the reluctance of European consumers to buy goods for the national currency; in this case, it also applies to hydrocarbon feedstock.

\section{Methods of research}

In the study using the method of theoretical analysis the concept of asymmetry and polarization of hydrocarbon resources in a small group of developing countries and countries with economies in transition was reflected. 
Active anti-dollar campaign is gradually unfolding in the world. These efforts often lead to serious and not always positive developments in global politics. The problem rejection of the dollar was investigated by the analysis of cause-effect relationships between phenomena. Washington's control over the trade in black gold is considered as the cause of geopolitics asymmetry. The consequence was a low level of confidence in the national currency in developing countries.

The purpose of the work is finding answers to the following questions by comparative analysis: what should be done to ensure that the rejection of the dollar would be real? What can the economy of the small developing country expect in global crisis, falling prices for raw materials, after two devaluations?

The method used in the study is analysis of the current situation not only from the macroeconomic, but also from the political point of view.

Also, the ways of solving the above-mentioned problem by other states are examined in detail, and comparative analysis is conducted in the case of applying these methods to Azerbaijan.

\section{Research results}

The strategic goal of any country's economic development is attracting of foreign investment; they characterize the long-term interest of foreign investors in the development of economic activity in a certain state. The stock market develops when investors appear on it, because the securities are needed for those issuers that have an area of business and profit. Moreover, it is important to take into consideration the negative investment climate for Azerbaijan, since there is a high probability of escalation of the Nagorno-Karabakh's conflict.

In the economy, there is a constant turnover of financial resources, which subjects are households, enterprises, the state and various financial institutions acting as intermediaries in the relations system. In the process of management, some subjects have a need for means to expand their activities, while others accumulate savings. The distribution of means occurs through the formation of funds: centralized or owned by the state, and decentralized or owned by the subjects of production. Until recently, the Azerbaijan government has practically ignored the possibility of attracting the financial resources of the population for infusion into the national economy. Practically bank deposits remained the only financial instrument to fill up the budget for the population. Nevertheless, two waves of devaluation of manat, and further closing of some banks (for today from 45 banks remained 33 acting credit institutions) considerably lowered trust of population to the banking system. In the developed countries of the world, income received from securities is an important additional source of money for the population. At the current stage, bonds issued by companies are more understandable for the population than the shares of certain companies. [20] shows as in 2017. 8 organizations issued bonds, with only 4 companies listed as non-state-owners - Amrahbank OJSC, Bakcell LTD, FINOKO Non-bank credit institution OJSC, UNIBANK CB OJSC (Table 1).

The population provides the bulk of investment in the stock market, if it has incomes that exceed consumption costs. Thus, the model of the undeveloped securities market in Azerbaijan is characterized by the fact that there are practically no national investment resources, national production cannot effectively consume foreign investment.

As [21] shows the economic reforms carried out in recent years in Azerbaijan ensured the establishment of an economic system operating based on free market relations. The fundamental institutions of the market economy have been formed, including the legislative framework that consolidates new economic relations.

Yet the situation in the world economy suits developing countries. They feel much better developed, their markets grow, which makes them real bait for investors. However «overly good» is also not good: capital flows from developed countries can lead to overheating and a crisis.

Azerbaijan does not have such risks - the economy falls into a lethargic dream: industry, investment, exports and GDP growth are generally slowing down, and this is the best medicine for overheating.

Let us return to the subject of abandoning the dollar in the calculations for oil supply. In our opinion, for Azerbaijan «rejection of the dollar» is nothing but a profanation. Such «refusals from the dollar» and the emerging systems of local mutual settlements are profanation because the instrument of mutual settlements is not important. An instrument for quoting these mutual settlements is important.

Table 1

Drganizations which issued bonds in 2017

\begin{tabular}{|c|c|c|c|c|c|c|c|}
\hline \multirow{2}{*}{ Period } & \multirow{2}{*}{ ISIN } & \multirow{2}{*}{ Emitent } & \multirow{2}{*}{ Nominal } & \multirow{2}{*}{ Curгепсу } & \multicolumn{3}{|c|}{ Transaction } \\
\hline & & & & & Price & Amount & Sum \\
\hline 30.03-12.09.2017 & AZ2001005167 & Amrahbank OJSC & 100 & USD & 100,0000 & 90170 & 9017000 \\
\hline 29.03-19.11.2017 & AZ2004008689 & Azerbaijan Mortgage Fund 0J5C & 1000 & AZN & 1005,1912 & 302024 & $303602,054,06$ \\
\hline 28.03-04.12.2017 & AZ2001019895 & SОСАR & 1000 & USD & 1008,7752 & 54864 & 55087720,4 \\
\hline 29.11-30.11.2017 & 000501001655 & Central Bank of the Azerbaijan Republic & 100 & AZN & 99,8197 & 122004 & 12178124,2 \\
\hline 18.09.2017 & AZ2002009465 & Bakcell LTD & 1000 & AZN & 1000,0000 & 2100 & 2100000 \\
\hline 17.04-17.08.2017 & AZ2001019465 & FINOKO Non-bank credit institution OJSC & 1000 & USD & 1000,0000 & 60 & 60000 \\
\hline 31.03-04.12.2017 & AZ0104001547 & The Ministry of finances & 100 & AZN & 95,8080 & 407446 & 37987529,92 \\
\hline 05.07-10.07.2017 & AZ2009002026 & UNIBANK CB OJSC & 1000 & AZN & 994,9000 & 4875 & 4850137,5 \\
\hline
\end{tabular}


No matter the countries name their currency, accepted for mutual settlements, they will continue to quote the rate of this currency (determine the value of the currency) and determine the value of the goods traded for it (determine the value of the goods) in the same petrodollars. Even in the mind, even if the conversion of the settlement currency to petrodollars is bypassed, the US dollar remains de facto a reference point for these countries - as the equivalent and the basic measure of value. Moreover, this means that, through the dollar exchange rate to the basket of major currencies (the dollar index) the US will retain its economic power over these countries and can still influence the economy and therefore the policies of these countries. What needs to be done to ensure that the rejection of the dollar will be real and not virtual?

To do this, countries need to sell their oil and gas, either for gold or for national currency tied to gold, and not to the US dollar, as it is now. Only the termination of quoting (assessment) in dollars of oil cost (value) and cost (value) of the used settlement monetary unit is capable to destroy world hegemony of petrodollar. Here a reasonable question arises: how to determine the value of oil relative to gold, without the participation of the US dollar, in which today both oil and gold are quoted (estimated) in world markets? The answer is «no way». It is just not necessary. The market itself will determine the relative value of oil against money (gold). It is only necessary to start selling oil for gold, according to the artificial proportions of values that we have today and which are expressed in US dollars. Moreover, in order to do this, there is no need even to announce the rejection of the dollar. It is enough simply to immediately exchange all dollars received from the sale of oil and gas for gold.

The change in oil prices has always had a strong impact on the course of trading. However, in the last 10 years the nature of this influence has changed dramatically.

Financial tools are a mechanism by which falling oil prices can cause a collapse in the stock market used finance exploration and oil production around the world, and especially in the United States. Modern oil exploration is financed through a variety of methods, including issuing shares to increase capital, as well as attracting finance through bonds and bank loans.

If the future expectations of the global economy are bad, people are trying to protect the dollar and gold and sell shares in countries where the stock market is developed. The price of gold is rising; the value of the dollar is rising against the national currency. When the price of the dollar rises, oil prices rise for developing economies, as it happens in Azerbaijan. This creates an additional burden on the economy, since inflation increases with energy costs. Because of high inflation, people invest more in gold and less in stocks, which leads to a drop in stock markets.

There are many combinations of oil, gold and shares, but as a rule:

- Gold and oil in developing countries are in inverse proportion: decreasing of oil prices testifies about bad times, then prices for gold increase respectively.

- Gold and shares in developed countries are in inverse proportion. If shares' prices increase, prices for gold decrease and vice versa.

\section{SWOT analysis of research results}

Strengths. Modern research notes a relatively high degree of asymmetry in the geopolitics of fuel. This is because the processes of the global economy are often characterized by both uniqueness and a high degree of uncertainty. As a consequence, forecasting the situation with geostrategic instability is difficult to assess, and therefore, there are difficulties associated with obtaining reliable information about it. The authors' research aims to assess the degree of information asymmetry in the context of this phenomenon's significance for developing countries, taking into account their absolute dependence on the dollar.

Weaknesses. As it was said above, oil is a trump card of all geopolitics, and the countries that have this card try to use it. The fact that foreign oil companies with billions dollars of debts, will pay for Iranian oil in euro, pushes the idea of the feasibility of the introduction of similar practices in our country. Nevertheless, can Azerbaijan refuse the dollar in foreign trade and switch to the euro after two devaluations? In addition, do we need this? For Azerbaijan, such step would be extremely dangerous, because at present limited influx of dollars is the main cause of instability in the financial market. The fact is that $90 \%$ of our exports are oil and oil products. The country has very few other dollar revenues. The price of oil is falling: the volume of the dollar coming to the republic is dropping, and the Central Bank is beginning to spend its foreign exchange reserves. And the value of gold expressed so far in US dollars, immediately starts to grow rapidly, both against the dollar, and against all goods-works and services. After a while in a certain market-defined trading range the oil-gold ratio will be stabilized naturally and the dollar will simply fall out of the formula for determining the price of oil and gold. On the contrary, the value of the dollar will begin to be measured in gold, as it should be and as it was throughout the entire monetary history of humankind. The value of national currencies has always been valued in money, i. e. in gold.

Opportunities. Research results indicate that the accumulation of huge monetary and financial resources has an ambiguous impact on the economy of oil-producing countries. On the one hand, it creates unprecedented financial conditions for boosting the economic development of these countries. On the other hand, it generates such problems as, for example, inflation growth, deepening of structural disproportions (flawed development of the «non-oil» sector), and difficulties in the social sphere. The development of entrepreneurship is closely linked with the development of small enterprises, the formation of the middle class and is conditioned by both internal and external factors. Investment activity is associated with the processes of the labor international division, attracting foreign investment, the investment projects' development.

The modern structure of the world in the postindustrial information space becomes very vulnerable. Therefore, in the very near future the development of oil fields with the correct configuration of the innovation process can move from massive technologies, requiring huge economic and industrial resources to point high-tech modules, whose development requires not so much capital investment, as creative flexibility and avant-garde approach.

The developing countries, to which Azerbaijan belongs, should develop this side of strategic asymmetry in priority. 
Threats. At the present stage of Azerbaijani economy development, foreign investments are directed mainly to the oil industry. Nevertheless, the proportional economic development requires an increase in investments in the oil industry or it is necessary to channel revenues from the sale of oil and oil products to the development of the non-oil sector. The increase in investments is necessary for the purposes of economic growth, limiting inflation and unemployment, creating new jobs. Money is not only the main goal of entrepreneurial activity, but also the most important means of its existence, since without the availability of money (initial investments) the emergence of entrepreneurial activity is impossible. At the same time, it is necessary to solve questions about the source of capital and its investment. One of the main subjects of business turnover in financial markets is securities.

There are more restrictions on foreign capital in Azerbaijan than in Eastern Europe and Central Asia. Under current legislation, a controlling stake in companies operating in the mining sector or oil and gas sector remains in the country. Among the most important measures to limit foreign investment are:

1. Establishment of special state control over the admission of foreign capital to the development of mineral and natural resources.

2. The prevention of foreign capital in certain sectors that is most important for the national economy.

3. Establishment of an obligatory share of participation of the national or private capital in the enterprises created by foreign firms (in the mixed societies).

4. Activities directed to use of some of foreign enterprises' profits for the domestic needs of developing country (taxation, restrictions when transferring profits abroad, etc.).

5. Definition of concession policy [22].

\section{Conclusions}

The results of theoretical research identify essential features of overcoming the dollar dependency and strategic objectives of oil dependent countries. For these aims:

1. The authors consider the geopolitical asymmetry associated with the dominance of the dollar in this market, analyze the existing political situation and offer their vision of republic's economy, for which oil has become a brake of development.

2. The manuscript shows in detail as developing countries including Azerbaijan, depend on developed countries. This is manifested primarily in the fact that developed countries are «pure» exporters of capital to developing countries, whereas developing countries are the debtors of developed countries. In foreign trade, economic dependence is manifested not only in the overall asymmetry of exports and imports, but also primarily in their market's commodity structure.

3. The authors focus on the development of entrepreneurship, which occupies an important place in social and economic policy, is an active participant in investment processes. In turn, investment processes define scientific and technical progress, modernization of economy, growth rates of branch and regional economies in essential degree. The paper considers the current state of this economic area, presents the dominant indicators for Azerbaijan in this sector. As a continuation of the theme of entrepreneurship develop- ment, the authors examine in detail the stock market of the republic, considering that the economy is based on the functioning of the corresponding financial system, and the most important place is occupied by the financial market on which there is the movement of money (capital).

4. As a logical conclusion of the study, the authors in the final part again return to the theme of oil's dedollarization, and, assessing all the shortcomings of the resource asymmetry from the perspective of a weak state, present their vision for solving this difficult problem.

\section{References}

1. Scholvin, S. Geopolitics. An Overview of Concepts and Empirical Examples From International Relations [Electronic resource] Handbook / S. Scholvin // FIIA Working Paper. - April, 2016. - Available at: \www/URL: https://www.files.ethz.ch/ isn/196701/wp91-Geopolitics.pdf

2. Meinhardt, H. I. Cooperative Decision Making in Common Pool Situation [Text]: Handbook / H. I. Meinhardt // Lecture Notes in Economics and Mathematical Systems. - Berlin: Springer Berlin Heidelberg, 2002. doi:10.1007/978-3-642-56136-8

3. Paul, T. V. Asymmetric conflicts: war initiation by weaker powers [Text]: Monograph / T. V. Paul. - New York: Cambridge University Press, 1994. - 250 p. doi:10.1017/cbo9780511598746

4. Karl, T. L. Oil-Led Development: Social, Political, and Economic Consequences [Electronic resource]: Handbook / T. L. Karl // CDDRL Working Papers No. 80. - January, 2007. - Available at: \www/URL: https://cddrl.fsi.stanford.edu/sites/default/ files/No 80 Terry Karl - Effects of Oil Development.pdf

5. Gladishev, D. A. Payment systems as elements of financial market infrastructure [Text] / D. A. Gladishev, M. B. Medvedeva // Finance, Money, Investments. - 2013. - No. 3 (47). - P. 10-13.

6. Frolov, F. IBM's SWIFT block-analog [Electronic resource] F. Frolov // Financial front. - October 10, 2017. - Available at: \www/URL: http://finfront.ru/2017/10/16/blockchainsubstitute-for-swift-from-ibm/

7. Banki ishhut sposoby, kak vlit'sya $\mathrm{v}$ bitkoin-dvizhenie [Electronic resource] // Rambler. - October 6, 2017. - Available at: \www/URL: https://news.rambler.ru/economics/38092142banki-hotyat-vlitsya-v-bitkoin-dvizhenie/

8. Geopolitics of Oil [Text] // Hearings before the Committee of Energy and Political Resources. US Senate, 96 Congress, the 2nd Session. - Washington: US gov., print. off., 1980. - Pt. 1-2.

9. International Energy Agency. «World Energy Outlook 2014» [Electronic resource] // International Energy Agency. - 2014. Available at: \www/URL: https://www.iea.org/publications/ freepublications/publication/WEO2014.pdf

10. Rumley, D. Geopolitical Orientations, Regionalism and Security in the Indian Ocean [Text]: Handbook / D. Rumley, S. Chaturvedi. - London: Taylor \& Francis e-Book, 2015. 320 p. doi: $10.4324 / 9781315689487$

11. Gutierrez, D. G. The Politics of the Interstices: Reflections on Citizenship and Non-Citizenship at the Turn of the Twentieth Century [Text] / D. Gutierrez // Race/Ethnicity: Multidisciplinary Global Contexts. - 2007. - Vol. 1, No. 1. - P. 89-120.

12. Davis, J. The Changing World of Oil: An Analysis of Corporate Change and Adaptation [Text] / J. Davis. - London: Routledge, 2006. - 213 p. doi:10.4324/9781315240787

13. Plummer, R. ALBA alliance ambitions lay bare Latin trade confusion [Electronic resource] / R. Plummer // BBC News. August 1, 2013. - Available at: \www/URL: http://www.bbc. $\mathrm{com} /$ news/business-23515979

14. Xiaochuan, Z. Reform the International Monetary System [Electronic resource] / Z. Xiaochuan // BIS Review. - March 23, 2009. - Available at: \www/URL: https://www.bis.org/review/ r090402c.pdf

15. Qiang, S. Russia quit dollar [Electronic resource] / S. Qiang, L. Xiaokun // China Daily. - November 24, 2010. - Available at: \www/URL: http://www.chinadaily.com.cn/china/2010-11/24/ content_11599087.htm

16. Proliferation Issues. JPRS Report. JPRS-TND-92-006 [Electronic resource] // Foreign Broadcast Information Service. March 13, 1992. - Available at: \www/URL: http://www. dtic.mil/dtic/tr/fulltext/u2/a333831.pdf 
17. Engdahl, W. Anglo-American Oil Market Is Broken [Electronic resource] / W. Engdahl // New Eastern Outlook. May 15, 2016. - Available at: \www/URL: https://journal-neo. org/2016/05/15/anglo-american-oil-market-is-broken/

18. World Oil and Gas Review [Electronic resource] // ENI. 2015. - Available at: \www/URL: https://www.eni.com/docs/ en_IT/enicom/media/press-release/2016/11/Eni_presents_15 edition_World_Oil_and_Gas_Review.pdf

19. Baumeister, C. Forty Years of Oil Price Fluctuations: Why the Price of Oil May Still Surprise Us [Text] / C. Baumeister, L. Kilian // Journal of Economic Perspectives. - 2016. Vol. 30, No. 1. - P. 139-160. doi:10.1257/jep.30.1.139

20. Baku Stock Exchange [Electronic resource]. - Available at: \www/ URL: http://bfb.az/eng/eqdler-ve-kotirovkalar/

21. Musayev, E. Securities Market In Azerbaijan: State And Tendencies Of Development [Text] / E. Musayev // Russian business. 2012. - No. 10. - Available at: \www/URL: http://cyberleninka. $\mathrm{ru} /$ article/n/rynok-tsennyh-bumag-v-azerbaydzhane-sostoyaniei-tendentsii-razvitiya

22. Guliyeva, A. Asymmetry in Fuel Geopolitics: Movement towards De-Dollarization and Strategic Objectives of the Development of Azerbaijan's Economy. [Text] / A. Guliyeva, U. Rzayeva // Proceedings book of 4th International Annual Meeting of Sosyoekonomi Society. - Vienna, October 27-28, 2017. - P. 97-99. Available at: \www/URL: http://www.sosyoekonomijournal.org/ AMSS17PB-B.pdf

\section{АНАЛИЗ ПРОБЛЕМЫ ДЕДОЛЛАРИЗАЦИИ В РАЗВИВАЮЩИХСЯ СТРАНАХ НА ПРИМЕРЕ АЗЕРБАЙДЖАНА В УСЛОВИЯХ ГЕОПОЛИТИЧЕСКОЙ АСИММЕТРИИ}

Исследована геополитическая асимметрия интересов между развитыми и развивающимися странами. В условиях глобального кризиса вопрос дедолларизации становится актуальным и с политической, и с экономической точек зрения. Рассмотрена проблема небольшого государства, возникшая на фоне нефтяной ловушки и постепенного отказа от использования доллара США в качестве валюты международных расчетов.

Ключевые слова: геостратегическая нестабильность, антидолларовая кампания, развитие предпринимательства, фондовый рынок, золото как денежная единица.

Guliyeva Aida, PhD, Associated Professor, Department of Information Economy and Technologies, Azerbaijan State University of Economy, Baku, Azerbaijan, e-mail: aida.quliyeva@sabah.edu.az, ORCID: https://orcid.org/0000-0001-5614-591X

Rzayeva Ulviyya, PhD, Lecturer, Department of Information Economy and Technologies, Azerbaijan State University of Economy, Baku, Azerbaijan, e-mail: ulviyya.rzayeva@unec.edu.az, ORCID https://orcid.org/0000-0001-5881-6633 